\title{
Review Essay: Armed Forces are not only for War
}

\author{
PETER WALLENSTEEN \\ University of Michigan and Dept. of Peace Research, University of Uppsala
}

\begin{abstract}
In two comprehensive studies published by the Brookings Institution, the historical record of US and Soviet uses of armed forces as political instruments short of war-fighting has been documented. The two studies, although not strictly comparable, provide very valuable sources of similar events, the study on the USA also using an interesting technique for deciding the outcomes. The general overview is complemented with detailed studies of particular cases, as well as a focus on some situations where nuclear threats were used. The studies suggest that a more limited American use of force would be advantageous and find that the Soviet Union uses force in a cautious manner. They do not, however, question the wisdom of weapons use, and do not systematically address questions of conflict escalation or conflict resolution. However, as a whole, the studies are a most important contribution to peace research.
\end{abstract}

During the post-1945 period the United States used its armed forces for specific political purposes 215 times. In a somewhat longer period, the Soviet Union used its forces for comparable purposes in 190 instances. This is the historical record described in two recent publications from the Washington-based Brookings Institution. In the study Force without War. US Armed Forces as Political Instruments (1978), Barry M. Blechman and Stephen S. Kaplan describe and evaluate US involvements from January 1, 1945 to December 31,1975 with the help of statistical overviews and diplomatic case studies. In Diplomacy of Power. Soviet Armed Forces as Political Instruments (1981), Stephen S. Kaplan compiles some overviews and presents eight different case studies of corresponding Soviet engagements from June 1944 to August 1979. Both volumes use as their point of departure an ambition to combine modern social science methods and historical accounts in order to provide some insight into the nonwar uses of armed forces. The historical record arrived at illustrates one of the main points: armed forces exist not only to wage war but also to exert pressure, demonstrate commitment, and 'project power'. Indeed, given the few war involvements of American and Soviet troops during the post-1945 period, 'political' uses seem more frequent than actual warfighting.
Although one of the authors has contributed to both volumes, each volume is distinctly different in method and analysis. The Blechman/Kaplan book embarks on an ambitious attempt to analyse the utility of the use of force. Thus, in a detailed study using a sample of the 215 incidents, an attempt is made to reach general conclusions on the usefulness of the US uses of armed forces. Some of the conclusions are quite striking, notably the finding that the overall strategic balance between the Soviet Union and the United States bears no systematic relations to the outcome of the US use of armed force. Thus, unfavorable and favorable outcomes (from the US point of view) are recorded in periods of nuclear superiority as well as under nuclear parity, also for incidents where the Soviet Union was a major participant. This clearly suggests that the 'strength' searched for in nuclear weapons does not very easily translate into policital utility in locally confined conflicts. No similar utility analysis is attempted for the Soviet uses of armed forces. Instead, the Soviet record is assessed in terms of its implications for American strategy.

Thus, both books are of policy relevance; the Blechman/Kaplan book in particular addresses the implicit question of excessive use of American force, whereas the Kaplan volume addresses the question of unpredictable Soviet use of force. By and large the 
conclusions seem to be, first, that the record of American successful uses of armed forces is not impressive either in a short-term or in a long-term perspective, but that some use of force is sometimes necessary. Secondly, the Soviet Union is found to act in a 'prudent' and 'cautious' manner when assisting allies outside of Eastern Europe, even while they are in direct confrontation with the United States. The pattern for Eastern Europe is different, however, the readiness for military intervention being higher.

Some of these conclusions appear trivial and guarded, but are, nevertheless, not without general interest. It should be made clear, however, that the volumes are parallel rather than comparative: there is no attempt to equate American or Soviet behavior. On the contrary, American intentions are described in quite operative terms, such as 'compel' and 'reinforce' while Soviet intentions are seen in more ominous light, such as 'expansions and defense of communism' and 'security of the Revolution'. This might not only reflect the lack of access to more detailed information on Soviet policy options, but also relate to an unwillingness to subscribe to a theory of general 'Big Power' behavior. Undoubtedly, the authors recognize a conflict between the United States and the Soviet Union of an ideological more than of a realpolitik character. The information supplied lends itself, however, to analyses also on other grounds, which makes the data collection useful to the entire research community. Certainly, studies of similar types on medium-sized or small states would be useful continuations, notably China, France, Israel or Libya.

\section{The data}

The Brookings reports aim at describing a historical record of uses of armed forces as political instruments. Inevitably, this leads to a whole set of border line decisions. The reports contain incidents where there is proof of (a) a deliberate attempt to influence (b) specific behaviour (c) of other states (d) without engaging in a continuing contest of violence. Thus, military threats are not counted unless they are combined with some military action, and military action which bears no relation to an attempt to influence is excluded. Furthermore, wars are not counted. This means that the studies try to record a middle level of uses of armed forces: the potential, latent impact of presence of armed forces in other countries is not recorded systematically (the presence of Soviet troops in Eastern Europe is not accounted for, unless it can be linked to some very specific political situation). Also, the actual physical imposition of will through war is excluded (the US war engagements in Korea and Vietnam are not dealt with). Of course these distinctions exclude some highly pertinent questions from the analysis and color some of the conclusions. For instance, Blechman/Kaplan find a decline in American uses of force as a political instrument since 1965 , although this very period exhibits the most heavy use of American force in an attempt to influence policies in another state (Vietnam). The rationale behind the exclusion can be accepted, but then some of the conclusions have to be qualified.

In a strictly comparative study, the criteria for excluding the Vietnam and Korea wars would also lead to the exclusion of Soviet interventions in Berlin, Hungary, and Czechoslovakia, as these are examples of the physical imposition of power. Kaplan argues that in none of these cases was the Soviet intention to fight a prolonged war, and thus the examples should be included. However, similar hopes might also have been in the minds of American decision-makers in 1965.

Some of these deficiencies are handled by the use of case studies, which means that the Soviet use of force in Eastern Europe is appropriately included. Also, the Soviet behavior is charted by starting the study as early as June 1944 (compared to January 1946 for the American study) which means that many of the events in the last two Second World War years are accounted for. The result is, however, that the total figures are not strictly comparable. ${ }^{1}$

The incidents included are not presented in detail in the volumes, although a great many 
of them are commented on in the text. Still, one could question the inclusion of some (notably a Swedish-Soviet incident in August 1967) and the exclusion of others (notably the Soviet note to Finland in 1961) in the Kaplan book and similarly in the other volume. Certainly, there is the problem of what a discrete incident is compared to a series of developments. Thus, the decision not to rely exclusively on statistical analysis but also to include historical-diplomatic narratives seems a wise one. It makes it possible for the reader to judge for himself the context in which the incidents take place.

\section{Conclusions on the United States}

Blechman/Kaplan find that the United States uses the navy to a particularly high degree for political influence attempts. This is a plausible conclusion (as Korea and Vietnam are not included), and perhaps not surprising: it stems from the US geographical location, being surrounded by oceans. More interesting is the proposition that such naval demonstrations tend not to be as 'successful' as other uses of force (success from a US perspective, of course). The authors argue that although naval forces may appear powerful, they do not symbolize commitment to the same extent as ground troops: ships can be moved in quickly, but equally quickly they can be withdrawn. Certainly, this conclusion has a policy implication, for instance, in seeing the significance of a renewed naval build-up (as now initiated in the United States). In a way, however, it lends some implicit support to the creation of a rapidly deployable ground force.

The authors also find that smaller forces or really significant ones (i.e. nuclear forces) have a higher association with outcomes favored by American policy makers. Particularly, the use of large forces (conventional and strategic nuclear) is singled out. Fifteen such incidents are located and in twelve the Soviet Union was an actor. In ten of the latter, the short-term outcome was positive for the United States, the authors assert. The incidents are all well-known to analysts, notably the repeated crises over Berlin, Cuba, and the
Middle East. The suggested favorable outcome for the United States in most of these events, of course, depends on an evaluation of what the American as well as the Soviet ambitions were. Although this might not be the intention of the authors, their conclusions lend support to those who demand 'tough' talk with the Russians. However, the authors caution the reader by suggesting that the very restricted use of nuclear weapons is related to the outcome: as they are so rarely used and are so dangerous, they clearly signal American commitment. In other words: only by very infrequently threatening the use of nuclear force does such force serve as a deterrent. The underlying theme is that the nuclear forces are useful as political instruments, and that the real problem is their application, not their existence. Still, the authors do not find that a general atmosphere of confrontation against the Soviet Union is in America's interest. On the contrary, the use of force achieves more favorable results for the US in periods of detente than in periods of tension.

The case studies in general take a more circumscribed view of the political uses of American armed forces. In a comparative study of the Laos 1962 and the Bengal 1971 crises, David K. Hall suggests that the application was successful in the first instance, but not in the latter. In general, the author warns against the utility of armed forces as big powers seldom have the control over their own allies as they (or their opponent) believe themselves to have: there is a serious risk of being drawn into undersirable situations. Similarly, Jerome N. Slater finds that the US intervention in the Dominican Republic in 1965 was not the wisest of US policy alternatives. In his studies of the Lebanon and Jordan crises of 1958 and 1970 respectively, William $B$. Quandt concludes that the outcome in the first one was successful due to a 'large element of chance', and in the second situation the outcome kept the American decisionmakers in a 'perceptual trap' which in turn stimulated the Middle East war in 1973.

The case studies on European events suggest a somewhat more positive appreciation 
of American armed behavior. Robert $M$. Slusser, in comparing the Berlin crises of 1958-59 and 1961, finds the Kennedy use of military instruments a 'remarkable success', but is more critical of Eisenhower's nonviolent way of handling the previous crisis. This conclusion is somewhat surprising in view of the fact that the 1958-59 crisis maintained the status quo in Berlin, whereas the 1961 one resulted in the construction of the Wall, changing an important part of the original Berlin arrangement.

In a study of Soviet military pressure on Yugoslavia in the early 1950's and on Yugoslavia and Rumania in 1968, Philip Windsor suggests that the USA 'succeeded in averting threats and containing crises' with its public statements and supporting military activity. Windsor also illustrates some of the perplexities that the break between the Soviet Union and Yugoslavia caused for the Western audience, being accustomed to a monolithic view of the 'Soviet bloc'.

The most troublesome problem in all these studies is the question of 'success'. It appears sometimes that the deployment of force more grows out of a consideration 'to do something' than of what is the appropriate way to support a diplomatic message or a political proposal. Furthermore, the time dimension is difficult to handle in a systematic manner. Is it really correct to see three years as a longterm period, no matter what the magnitude of the threat?

\section{Conclusions on the Soviet Union}

Longer long-term considerations are in the forefront in the Kaplan book on the Soviet uses of armed forces. The nuclear threat exerted by the Soviet Union in 1969 against China is an example of an action that in the short-term brought about negotiations on the border issue and lowered tension, probably as desired by the Soviet Union. In the long-run, however, it strengthened China's interest in opening up to the West. Thomas W. Robinson refers to the 'hint' of such a nuclear threat, whereas Kaplan himself leaves no doubt about the threat and its immediate im- pact: 'In the one instance when the USSR raised the spectre of nuclear war, China quickly compromised'. Kaplan, however, notes that the Soviet Union 'went beyond what was required' and that this threat drove China closer to the West and alarmed NATO and Japan as well. Robinson gives little information on this incident, beyond a reference to the journalist Victor Louis. It is not included in the list of the 190 incidents given in the book. Still, the nuclear option appears to have been developed by the Soviet Union during 1969, and it thus achieves an appropriate place in the Kaplan volume.

At the other end of the spectrum, Michel Tatu's analysis of Soviet interventions in Eastern Europe is illuminating. Tatu finds that the latent pressure existing from the presence of Soviet troops in Eastern Europe might keep internal Communist Party conflicts at a low level. The overt uses of force in the forms of, inter alia, maneuvers are less effective or even counter-productive in bringing a local leadership in line with Soviet wishes. The overwhelming military superiority, one might conclude, does not inject fear, but rather appears as 'overkill' making it ineffective as a threat. Thus, Soviet physical imposition of power becomes a possibility. But not always so. Additional insights might have been gained from a closer scrutiny of cases where local Communist leaders actually have been able to maintain control for themselves and autonomy for their countries in spite of Soviet pressure (Yugoslavia, Rumania, and Albania).

The other essays in Kaplan's book deal with the relative reluctance of the Soviet Union to commit Soviet soldiers to the defence of allied countries. The cases most clearly in mind are the Korean and Vietnam wars. William Zimmerman notes that 'force is most effectively applied when it is not actually used', in line with the above reasoning. Koreans and Vietnamese, being able to handle the situation much on their own, would consequently need no Soviet troops (they might not have wanted any either?) and the deliveries of Soviet materiel would have satisfied all 
parties. Zimmerman notes, however, that the Soviet Union did nothing elsewhere to weaken the American interventions.

Still, Zimmermann concludes that in particular the Soviet policy in the Vietnam war 'probably reassured the Soviet elite about the wisdom of its course ... (and) reinforced the Soviet Union's belief that it could engage profitably in other low-risk efforts' without jeopardizing relations with the United States. This contrasts with the conclusions drawn by Paul Jabber and Roman Kolkowicz on Soviet 'lessons' from the 1967 and 1973 Arab-Israel wars: 'retaining influence over client states... may require a commitment to military intervention on the client's behalf when necessary, even at the risk of nuclear confrontation'. The lack of vigorous support for the Arab countries after the 1967 war had a more lasting impact than the intensive arm shipments during the October war, they conclude. Thus, these case studies do not help us (or the Soviets!) to understand the Soviet Union. Uncertainty about Soviet preferences in general (low-risk or high-risk policy?) is central to the prevailing image of Soviet unpredictability.

Still, this is the very image that Kaplan wants to dispell. In his conclusion, he suggests that Soviet military operations usually have been 'expected and plausible', not unpredictable or part of a threatening, unexplainable expansionist drive. Only in very few instances can the Soviet Union be expected to use serious coercive military means, Kaplan states, and then proceeds to formulate a possible American strategy to this. Its important elements are to appear strong, motivated and powerful, as the Soviet Union is sensitive to US uncertainty. Somewhat in contradiction to the first volume, Kaplan illustrates such U.S. behavior with big naval shows of force: at least two aircraft carrier task groups can sometimes be an appropriate response to Soviet deployments.

Although Kaplan's analysis appears somewhat confined and monotonous in its focus on variables such as 'confidence', 'moves', 'appearance' and with actors referred to as 'Moscow' or 'Kremlin', it nevertheless is use- ful. The attempt to find a rationale behind Soviet behavior, to see it as predictable and cautious, runs counter to prevailing non-academic analysis of the Soviet Union. Particularly useful is the distinction between Soviet behavior in Eastern Europe and Northern Asia versus its activities elsewhere in the Third World. Unfortunately, however, Kaplan does not comment at all on the invasion in Afghanistan. It would, of course, not qualify under the criteria used for inclusion, unless one assumes that the Soviet leadership expected this to be a speedy operation similar to the ones in Eastern Europe. But even so, it does not fit the general pattern suggested by Kaplan which is that once the Soviet Union employs ground forces it uses a lot of them: in Afghanistan the highest number of Soviet troops mentioned is 100,000 men, compared to the 400-500,000 men used in Czechoslovakia. Furthermore the operation takes place in a region which cannot be regarded as important for Soviet security, particularly not after the fall of the US-supported Shah. Thus, the Soviet action might in this case be neither 'expected' nor 'plausible'.

\section{Conclusion on the Brookings reports}

The two volumes provide an extensive review of the uses of armed forces for specific concrete political purposes. As such, they constitute a useful addition to the listings of wars, civil wars, military confrontations, and armed conflicts already available to the peace research community. As is always the case with such listings, some of the inclusions and exclusions can be debated. The importance of some decisions can be marginal for the analysis, but in this case, the exclusion of the Korean, Vietnam, and Afghanistan wars has important implications. The case study approach might thus have been extended to include these situations as well, rather than to neglect them entirely.

The attempt to analyse 'favorable' outcomes is quite original and of significance for continued research. The method used in the Blechman/Kaplan volume meets reasonable criteria. The method employed in the Kaplan 
book to systematically compare Soviet behavior is one of counter-factuality: what did the Soviet Union not do (in order to appreciate the degree of caution used), when did it do what it did (in order to evaluate the degree of provocation involved). This is handy, but problematic, as disagreements easily arise on which policy options actually were available in these situations.

The major deficiency in these studies is, however, the lack of discussion on the implications of armed uses on conflict escalation, emergence of new conflicts, and the possibility to create lasting peaceful settlements. Kaplan concludes that the United States has to respond to Soviet 'moves' and that this will present the Third World with an option: a choice between maintaining regional autonomy or inviting American-Soviet rivalry. Given such a US policy, this might simultaneously stimulate independence from the Soviet Union and restrain Soviet behavior, he claims. However, the two volumes make little effort to look into the historical record of such local effects of the big power uses of armed forces. They merely note the general hesitancy of both big powers to use force when the other one is engaged in actual combat. The interaction effects on the local level would, however, be possible to study in a combined volume, using the data supplied by both books. This, furthermore, might lay some groundwork for an analysis of escalation of armed behavior, and to the problem referred to in some case studies, namely the possibility that the big powers may be trapped by their own perceptions and by the actions of their own allies. In a time when both powers refrain from using their own troops in distant conflicts, and prefer to operate through intermediaries, the significance of such allies might be increasing. The Nixon doctrine certainly has its Soviet equivalent as demonstrated both by Vietnam and Cuba. As allies are not completely controllable, the superpowers may in the near future face some dramatic surprises. The Brookings reports may have prepared us for some of them, but would have gained from a heavier emphasis on the independence of many of the Third World states.

\section{NOTE}

1. Strict numerical comparability can be achieved by counting incidents from Jan 1, 1946 to Dec 31, 1975 which gives a total of 215 incidents for the United States and 156 for the Soviet Union. However, this means that the establishment of Soviet control in East Europe is almost completely neglected. Exact comparability, in other words, might not be desirable, when the realities are not strictly comparable in themselves. 